Irfan Saputra, M. Fachri Adnan I Pengaruh Kandidat dan Ikatan Sosial terhadap Perilaku Pemilih Pemula dalam Pemilihan Legislatif Tahun 2019 di Kecamatan Tilatang Kamang

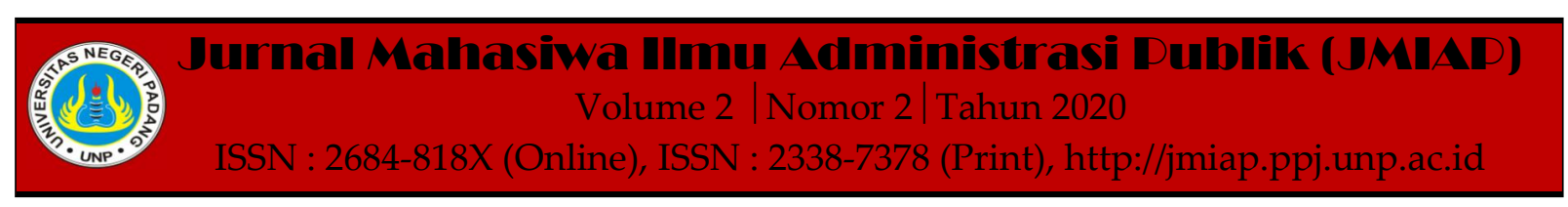

\title{
PENGARUH KANDIDAT DAN IKATAN SOSIAL TERHADAP PERILAKU PEMILIH PEMULA DALAM PEMILIHAN LEGISLATIF TAHUN 2019 DI KECAMATAN TILATANG KAMANG
}

\author{
Irfan Saputra $^{1(a)}$, M. Fachri Adnan ${ }^{2(b)}$ \\ ${ }^{1}$ Jurusan Ilmu Administrasi Negara, Universitas Negeri Padang \\ ${ }^{2}$ Jurusan Ilmu Administrasi Negara, Universitas Negeri Padang \\ a)irfan.spt31@gmail.com, b)fachriadnan@fis.unp.ac.id
}

\begin{abstract}
This research aims to find out determine the effect of candidates and social ties on the behavior of novice voters in the 2019 legislative elections in kecamatan Tilatang Kamang. The background of the research is how the behavior of the novice voters sees from candidat image and the social ties that exist in their environment, Kecamatan Tilatang Kamang. This type of the research is quantitative research. The independent variable of this research are candidates and social ties, and dependent variable is novice voters behavior. The population of the research were the novice voter in Kecamatan Tilatang Kamang. Kecamatan Tilatang Kamang consists of three Kenagarian, Kenagarian Gadut, Kenagarian Koto Tangah, and Kenagarian Kapau. Sampling is by using the slovin formula and the sampling technique in this research is proporsional stratified random sampling. The sampling in the research totaled 96 novice voter in Kecamatan Tilatang Kamang. Data collection in this study use a questionnaire with a Likert scale. After that, the classical assumption test consist of normality test, linearity test, heteroscesdasticity test, multicoloniality test, and autocorrection test. Futhermor, a analysis multiples linear regression. The result showed that there was a significant the effect of candidates and social ties on the behavior of novice voter in the 2019 legislative elections in Kecamatan Tilatang Kamang.
\end{abstract}

Keywords : Candidates, Social Ties, Novice Voters Behavior

Corresponding author. Email.irfan.spt31@gmail.com,fachriadnan@fis.unp.ac.id

How to cite this article. Saputra, I \& Adnan, F. Facri. (2020). Pengaruh Kandidat dan Ikatan Sosial terhadap Perilaku Pemilih Pemula dalam Pemilihan Legislatif Tahun 2019 di Kecamatan Tilatang Kamang. Jurnal Mahasiwa Ilmu Administrasi Publik (JMIAP) Jurusan Ilmu Administrasi Negara Fakultas Ilmu Sosial Universitas Negeri Padang, Volume 2 (2), Hal. 1-8.

http://jmiap.ppj.unp.ac.id

ISSN : 2684-818X (Online), ISSN : 2338-7378 (Print)

Copyright $\bigcirc 2020$. Published by Pusat Kajian-Pemberdayaan dan Pelayanan Masyarakat (PK-P2M) FIS UNP Padang 


\section{PENDAHULUAN}

Pemilu adalah sarana kedaulatan rakyat untuk memilih anggota dewan perwakilan rakyat, dewan perwakilan daerah, presiden dan wakil presiden, dan untuk memilih anggota dewan perwakilan rakyat daerah. Pemilu harus dilaksanakan secara langsung, umum, bebas, rahasia, jujur, adil dalam Negara Kesatuan Republik Indonesia berdasarkan Undang-undang dasar tahun 1945. Pemilu merupakan salah satu pelaksanaan kedaulatan rakyat yang berdasarkan kepada demokrasi perwakilan. Pemilu juga dapat diartikan sebagai mekanisme penyeleksian dan penyerahan kedaulatan kepada orang atau partai yang dipercaya. Salah satu faktor yang mempengaruhi hasil pemilu adalah perilaku dari rakyat yang ikut berpartisipasi dalam pemilihan umum tersebut. Menurut Surbakti (1992) bahwa perilaku memilih adalah suatu kegiatan pemberian suara oleh seseorang yang berkaitan erat dengan kegiatan pengambilan keputusan untuk memilih atau tidak memilih pada suatu pemilihan umum.

Salah satu elemen penentu dalam pemilihan umum adalah pemilih pemula. Pemilih pemula dalam Undang-undang nomor 7 tahun 2017 adalah mereka yang baru pertama kali memilih dan berusia 17 atau lebih. Pemilih pemula ini dianggap tidak memiliki pengalaman pada pemilihan umum sebelumnya. Diana, dkk (2014) mengatakan bahwa kurangnya pengalaman pemilih pemula dalam memilih, mengakibatkan pemilih pemula kebinggungan disaat dihadapkan kepada banyaknya calon legislatif yang harus dipilih dalam pemilihan umum. Selain itu menurut Diah dan Mudzakkir (2016) bahwa motif atau dorongan pemilih pemula untuk ikut dalam pemilihan umum adalah motif peer group, dimana pemilih pemula ini yang pada awalnya tidak antusias untuk memilih dalam pemilihan umum menjadi antusias karena dorongan dari teman sebayanya. Hal tersebut akan membuat pemilih pemula tersebut mendapatkan suasan yang menyenangkan.
Permasalahan yang ditemukan di Kecamatan Tilatang Kamang adalah masih kurangnya partisipasi memilih masyarakat dalam pemilihan umum. Menurut data Komisi Pemilihan Umum Kabupaten Agam menyatakan tingkat partisipasi masyarakat Kecamatan Tilatang Kamang sebesar $70,3 \%$ termasuk didalamnya pemilih pemula. Dibandikan dengan Kecamatan lain di Kabupaten agam seperti Kecamatan Baso sebesar 71,6\%, Kecamatan Banuhampu sebesar $72 \%$, dan Kecamatan Palupuh sebesar 71,7\%. Partisipasi memilih masyarakat Kecamatan Tilatang Kamang masih rendah termasuk didalamnya pertisipasi pemilih pemula.

Berdasarkan latar belakang diatas penulis sudah melakukan penelitian tentang Pengaruh Kandidat Dan Ikatan Sosial Terhadap Perilaku Pemilih Pemula Pada Pemilihan Legislatif Tahun 2019 di Kecamatan Tilatang Kamang dengan tujuan penelitian ini menjelaskan pengaruh kandidat dan ikatan sosial terhadap perilaku pemilih pemula pada pemilihan legislatif tahun 2019 di Kecamatan Tilatang Kamang.

\section{TINJAUAN PUSTAKA Perilaku Politik}

Perilaku politik menurut Ramlan Surbakti (1992) adalah sebagai kegiatan yang berkenaan dengan proses pembuatan dan keputusan politik. Perilaku politik merupakan salah satu unsur atau aspek perilaku secara umum. Menuut Miaz (2012) perilaku politik meliputi tanggapan internal seperti persepsi, sikap, orientasi dan keyakinan serta tindakan-tindakan nyata seperti pemberian suara, lobi, protes, dan lain-lain. Jadi dapat disimpulkan bahwa perilaku politik adalah bagaimana cara aktor politik bertingkah laku dalam menanggapi maupun melakukan kegiatan yang berbaur politik. Baik tingkah laku politik pemerintah sebagai pembuat kebijakan, mauapun tingkah laku masyarakat yang menerapkan kebijakan tersebut.

Perilaku politik didalam Pontoh (2013) menyatakan bahwa sebagai keseluruhan 
tingkah laku politik para aktor politik dan warga negara yang dalam manifestasi kongkritnya telah saling memiliki hubungan. Perilaku politik dinyatakan sebagai suatu telaah mengenai tindakan manusia dalam situasi politik. Interaksi antara pemerintah dan masyarakat anatara lembaga-lembaga pemerintah dan antara kelompok individu dalam masyarakat.

\section{Pendekatan Perilaku Pemilih}

Salah satu bentuk perilaku politik adalah perilaku pemilih. Perilaku pemilih dalam Adnan (2012) adalah tindakan seseorang memilih sesuatu dalam suatu pertemuan atau musyawarah. Dalam perilaku memilih dalam suatu pemilihan umum tidak hanya sebagai perilaku yang bersifat individu saja akan tetapi perilaku pemilih juga dipengaruhi oleh unsur refleksi struktural social budaya, ekonomi, dan politik. Ada tiga pendekatan yang sering digunakan dalam memahami perilaku memilih:

1) Pendekatan Sosiologis

Pendekatan sosiologis dalam Adnan (2012) dikenal dengan Sosiological school atau mazhab Columbia. Menurut penganut mzhab ini masyarakat terdiri dari atas kesatuan status yang bertingkat. Masyarakat berstruktur oleh norma-norma dan dipengaruhi oleh pengelompokan sosial berdasarkan agama, kelas sosial, pekerjaan dan lain-lain. Oleh sebab itu, perilaku pemilih dalam pemilihan umum dikarenakan karena pengelompokan sosial tadi akan berpengaruh terhadap perilaku pemilih. Menurut Sholihin (2009) menjelaskan bahwa pendekatan soiologis memiliki kekurangan terletak pada sulitnya mengukur secara indikator kelas sosial, tingkat pendidikan, dan agama.

2) Pendekatan Psikologis

Pendekatan ini dikembangkan oleh para peneliti dari Survey Research Centre, The University Michigan. Oleh karena itu pendekatan ini dikenal juga dengan Mazhab Psikologi. Para pendukung pendekatan ini berpendepat bahwa Keputusan seseorang pemilih dipengaruhi oleh kekuatan psikologi seseorang. Seperti keputusan dalam memilih sebuah partai atau calon dalam suatu pemilihan umum merupakan suatu output dari sikap psikis seseorang atau pemilih itu sendiri. Miaz (2012) menjelaskan bahwa pendekatan ini lebih melihat perilaku pemilih dengan mengkaji diri dari individu tersebut. Menurut mereka, persepsi dan penilaian pribadi terhadap kandidat atau tema-tema yang diangkat sangat berpengaruh terhadap pilihan mereka dalam pemilu. Pendekatan ini mendasari faktor perilaku pemilih seperti faktor psikologi atau sikap mempengaruhi perilaku memilih seseorang seperti hubungan seseorang dengan partai politik maupun perasaan seseorang terhadap seorang kandidat. Sholihin (2009) pendekatan ini menekankan kepada tiga aspek psikologis sebagai kajian utamanya. Pertama, ikatan emosional pada suatu partai politik, kedua orientasi kepada isu-isu, dan ketiga orientasi kepada calon/kandidat.

3) Pendekatan Rasional

Pendekatan ini disponsori oleh Anthony down yang mengembangkan teori ini berdasarkan asumsi teori ekonmi modern yang rasional sehingga pendekatan ini juga disebut dengan pendekatan ekonomi. Ramlan Surbakti (1992) mengemukan pendekatan ini bahwa pendekatan rasional ini melihat dari sisi atau melihat kegiatan memilih sebagai produk kalkulasi untung dan rugi. Melihat apakah sebarapa modal yang akan dikeluarkan dan kemungkinan suara yang diaharapkan dapat mempengaruhi hasil yang didapat dalam pemilu tersebut, tetapi juga perbandingan dari alternative pilihan yang tersedia juga dipertimbangkan. Pemilih akan berpihak kepada pilihan yang dapat menguntungakan bagi mereka.

\section{Faktor-Faktor yang Mempengaruhi Perilaku Pemilih}

1) Kelas Sosial

Kelas sosial memberikan pengaruh terhadap perilaku pemilih. Berdasarkan kajian Amerika dalam Adnan (2012) menjelaskan adanya kecendrungan bahwa pemilih yang mempunyai pendapatan 
rendah, pekerja bermata biru, dan pekerja suatu perusahaan secara tradisional cendrung memilih partai demokrat. Sedangkan orang yang lebih professional atau manajer, lulusan perguruan tinggi, dan orang yang tidak menjadi anggota organisasi cendrung lebih memilih partai republik. Dari kajian tersebut dapat disimpulkan bahwa perilaku pemilih berdasarkan kelas sosial dapat dilihat dari bagaimana isu-isu yang diberikan oleh partai tersebut yang akan memberikan keuntungan pada suatu kelas tertentu.

Selain itu dalam salah satu indikator dalam kelas sosial ini adalah agama. Agama merupakan suatu unsur yang sangat penting dan menjadi dasar manusia dalam berperilaku. Dalam perilaku memilih, agama menjadi pembentukan perilaku dalam suatu pemilihan umum. Dalam penelitian Emilia \& Wawan (2015) bahwa agama menjadi dasar masyarakat dalam memilih. Dari hasil penelitian ini masyarakat lebih cendrung memilih calon yang memiliki keyakinan yang sama dengannya.

2) Kandidat

Dalam pemilihan langsung, kandidat atau calon yang berasal dari daerah bersangkutan, tentu akan lebih dikenal oleh pemilih. Kandidat merupakan faktor penentu yang mempengaruhi perilaku pemilih dalam pemilihan umum. Dimana kuliatas kandidat akan menjadi daya tarik tersendiri bagi pemilih. Hal tersebut diperkuat dalam penelitian Sara Binzer Holbot dan Bjorn Hoyland (2007) dalam Adnan (2012) dimana penelitian tersebut mengatakan bahwa kualitas kandidat akan dapat meningkatkan partisipasi pemilih.

Selain itu Stephen Franzoi juga berpendapat dalam penelitian Emilia dan Wawan (2015) berpendapat bahwa apabila kandidat atau calon mempunyai kredibilitas, terpercaya, dan berkompetensi tinggi maka pesan yang disampaikan pemilih akan lebih diperhatikan. Oleh karena itu perilaku pemilih akan melihat bagaimana latar belakang kandidat atau calon yang akan duduk pada kursi pemerintahan. Selain itu faktor isu-isu dan program memberikan pengaruh terhadap perilaku pemilih. Dimana besarnya perhatian masyarakat terhadap persoalan yang dihadapi bangsa, strategisnya faktor isu disebabkan oleh faktor kebebasan partai politik atau kandidat dalam mengemas isu dan programnya. Pada umumnya penguat faktor isu dan program disebabkan oleh peningkatan pendidikan dan daya kritis masyarakat.

Adnan (2012) menyatakan ada dua teori yang digunakan untuk menganalisis isu terhadap perilaku pemilih. Pertama, teori restorpective voting yang menjelaskan dalam menentukan keputusan memilih pada pemilihan umum, ada pemilih yang menentukan pilihannya berdasarkan penilaiannya terhadap kinerja partai/pemerintah pada masa lalu. Kedua, teori prospective voting yang menjelaskan dalam menentukan keputusan memilih dalam pemilihan umum, ada pula warganegara memilih berdasarkan penilaiannya terhadap program terbaik yang disampaikan pada masa kampanye yang logis dan dapat dilaksanakan pada masa yang akan datang.

Jadi dengan adanya isu-isu tersebut dapat menjadi dasar pemilih untuk memilih mana yang pantas untuk dipilih. Pemilih akan menentukan bagaimana isu-isu yang telah dilaksanakan masa lalu dan bagaimana isu-isu pada masa yang akan datang.

\section{METODE PENELITIAN}

Penelitian ini menggunakan metode kuantitatif dengan menggunakan analisis korelasi. Penelitian ini penulis lakukan di sebuah Kecamatan di Kabupaten Agam yaitu Kecamatan Tilatang Kaman. Populasi dalam penelitian ini adalah pemilih pemula yang berdomisili di daerah Kecamatan Tilatang Kamang yang berjumlah 2575. Sampel dalam penelitian ini diseleksi dengan rumus slovin dengan tingkat kesalahan $10 \%$. Sampel yang didapat adalah 96 orang responden pemilih pemula di Kecamatan Tilatang Kamang. 
Irfan Saputra, M. Fachri Adnan | Pengaruh Kandidat dan Ikatan Sosial terhadap Perilaku Pemilih Pemula dalam Pemilihan Legislatif Tahun 2019 di Kecamatan Tilatang Kamang

Pengambilan sampel dalam penelitian ini menggunakan teknik Simple Random Sample.

Pengumpulan data melalui angket/Kuisioner yang dibagikan kepada pemilih pemula yang ada di Kecamatan Tilatang Kamang. Variabel bebas (idependent variable) dalam penelitian ini adalah Kandidat (X1) dan Ikatan Sosial (X2) dan variabel terikat (dependent variable) adalah Perilaku Pemilih Pemula (Y). Pengukuran data menggunakan skala likert. Data yang diperoleh kemudian dianalisis uji asumsi klasik uji parsial dan uji regresi linier berganda dengan menggunakan software SPSS versi 23.0.

\section{HASIL DAN PEMBAHASAN \\ Temuan Penelitian}

Sebelum melihat analisis dari hubungan variabel $\mathrm{X}$ dan $\mathrm{Y}$, data penelitian ini harus memenuhi asumsi atau persyaratan dari uji asumsi klasik. Setelah diuji, data dari penelitian ini sudah memenuhi persyaratan uji asumsi klasik dan selanjut dilakukan analisi hubungan antara variabel $\mathrm{X}$ dan $\mathrm{Y}$. analisa tersebut dilihat melalui pengaruh variabel $\mathrm{X}$ dan variabel $\mathrm{Y}$ secara parsial dan pengaruh variabel $\mathrm{X}$ dan $\mathrm{Y}$ secara simultan dengan uji regresi berganda.

Berikut adalah hasil dari uji parsial variabel kandidat (X1) dan variabel ikatan sosial terhadap variabel perilaku pemilih pemula (Y):

\section{Tabel 1. Uji Parsial Pengaruh Kandidat dan Ikatan Sosial terhadap Perilaku Pemilih} Pemula dalam Pemilihan Legislatif Tahun 2019 di Kecamatan Tilatang Kamang

Coefficients $^{\text {a }}$

\begin{tabular}{|c|c|c|c|c|c|c|c|}
\hline \multirow[b]{2}{*}{ Model } & \multicolumn{2}{|c|}{$\begin{array}{c}\text { Unstandardized } \\
\text { Coefficients }\end{array}$} & \multirow{2}{*}{$\begin{array}{c}\text { Standardized } \\
\text { Coefficients } \\
\text { Beta } \\
\end{array}$} & \multirow[b]{2}{*}{$\mathrm{t}$} & \multirow[b]{2}{*}{ Sig. } & \multicolumn{2}{|c|}{$\begin{array}{l}\text { Collinearity } \\
\text { Statistics }\end{array}$} \\
\hline & $\mathrm{B}$ & $\begin{array}{l}\text { Std. } \\
\text { Error }\end{array}$ & & & & Tolerance & VIF \\
\hline (Constant) & -5.946 & 2.129 & & -2.793 & .006 & & \\
\hline Kandidat(X1) & .437 & .079 & .498 & 5.543 & .000 & .882 & 1.134 \\
\hline Ikatan_Sosial(X2) & .205 & .106 & .173 & 1.923 & .058 & .882 & 1.134 \\
\hline
\end{tabular}

a. Dependent Variable: Perilaku_Pemilih (Y)

Berdasarkan tabel 1 diatas dapat dilihat bahwa nilai signifikansi pengaruh kandidat didapat 0,000 . Artinya, jika nilai sig. $<0,05$ terdapat pengaruh variabel kandidat (X1) terhadap perilaku pemilih pemula dalam pemilihan legislatif tahun 2019 di Kecamatan Tilatang Kamang. Jadi dapat disimpulkan bahwa Ho ditolak, Ha diterima. Temuan penelitian ini mendukung mendukung hasil penelitian terdahulu yang mengkaji permasalahan yang sama dengan penelitian ini. Penelitian Adnan (2012) dalam penelitian perilaku memilih pada pemilihan gubernur Sumatera Barat tahun 2005 yang menemukan adanya pengaruh kandidat terhadap perilaku memilih tersebut yang digambarkan dalam dua dimensi yakni dimensi kepribadian dan dimensi kepemimpinan. Dimensi tersebut juga dituangkan dalam penelitian ini.

Sedangkan pada variabel ikatan sosial ditemukan nilai signifikansi sebesar 0,06. Berarti variabel tersebut tidak signifikan karna nilai signifikansi lebih besar dari 0,05. Jadi dapat disimpulkan bahwa Ho diterima, Ha ditolak yang artinya tidak terdapat pengaruh ikatan sosial terhadap perilaku politik pemilih pemula dalam pemilihan legislatif tahun 2019 di Kecamatan Tilatang Kamang. Selanjutnya dilakukan uji simultan pengaruh kandidat (X1) dan ikatan sosial (X2) terhadap perilaku pemilih pemula(Y): 
Irfan Saputra, M. Fachri Adnan | Pengaruh Kandidat dan Ikatan Sosial terhadap Perilaku Pemilih Pemula dalam Pemilihan Legislatif Tahun 2019 di Kecamatan Tilatang Kamang

Tabel 2. Pengaruh Kandidat dan Ikatan Sosial Secara Simultan terhadap Perilaku Pemilih Pemula dalam Pemilihan Legislatif Tahun 2019 di Kecamatan Tilatang Kamang

Model Summary ${ }^{b}$

\begin{tabular}{l|r|r|r|r|r}
\hline Model & R & R Square & $\begin{array}{c}\text { Adjusted R } \\
\text { Square }\end{array}$ & $\begin{array}{l}\text { Std. Error of } \\
\text { the Estimate }\end{array}$ & $\begin{array}{l}\text { Durbin- } \\
\text { Watson }\end{array}$ \\
\hline 1 & $.581^{\mathrm{a}}$ & .337 & .323 & 1.652 & 1.651 \\
\hline
\end{tabular}

a. Predictors: (Constant), Ikatan_Sosial(X2), Kandidat(X1)

b. Dependent Variable: Perilaku_Pemilih(Y)

Tabel 3. Uji ANOVA (F) Pengaruh Kandidat dan Ikatan Sosial terhadap Perilaku Pemilih Pemula dalam Pemilihan Legislatif Tahun 2019 di Kecamatan Tilatang Kamang

ANOVA $^{a}$

\begin{tabular}{ll|r|r|r|r|r}
\hline \multirow{2}{*}{ Model } & $\begin{array}{c}\text { Sum of } \\
\text { Squares }\end{array}$ & df & Mean Square & F & \multicolumn{1}{c}{ Sig. } \\
\hline 1 & Regression & 129.198 & 2 & 64.599 & 23.675 & $.000^{\mathrm{b}}$ \\
\cline { 2 - 7 } & Residual & 253.760 & 93 & 2.729 & & \\
\cline { 2 - 8 } & Total & 382.958 & 95 & & & \\
\hline
\end{tabular}

a. Dependent Variable: Perilaku_Pemilih(Y)

b. Predictors: (Constant), Ikatan_Sosial(X2), Kandidat(X1)

Berdasarkan tabel 3 tersebut, bahwa hasil uji ANOVA (F) didapati hasil signifikansi pengaruh atau nilai sig. menunjukan angka $0,000^{\mathrm{b}}$. Artinya terdapat pengaruh dari kandidat dan ikatan sosial terhadap perilaku pemilih pemula pada pemilihan legislatif tahun 2019 di Kecamatan Tilatang Kamang. Penelitian ini memiliki pengaruh signifikan dan hasil uji regresi berganda ini dapat dipercaya $100 \%$.

Selanjutnya pada tabel 2 diatas dapat dilihat bahwa hasil Adjusted $R$ Square yang diperoleh melalui hasil analisis regresi sebesar 0,323. Artinya besar pengaruh kandidat (X1) dan ikatan sosial (X2) terhadap perilaku pemilih pemula (Y) secara simultan adalah sebesar $32 \%$. Sementara sisanya sebesar $68 \%$ dipengaruhi oleh variabel lain yang tidak diteliti dalam penelitian ini. Selain itu.

Berdasarkan hasil temuan yang telah dijelaskan bahwa peneliti memaparkan tentang pengaruh kandidat dan ikatan sosial terhadap perilaku pemilih pemula dalam pemilihan legislatif tahun 2019. Setelah dilakukan penelitian dan dilanjutkan dengan menganalisis data dari analisis data yang telah dilakukan hal ini membuktikan bahwa secara parsial kandidat berpengaruh terhadap perilaku pemilih pemula dalam pemilihan legislatif tahun 2019 di Kecamatan Tilatang Kamang. Hal tersebut dibuktikan bahwa dari temuan statistik pengolahaan data menggunakan SPSS versi 25 ditemukan nilai sig variabel kandidat sebesar 0,000. Dapat disimpulkan bahwa adanya pengaruh yang signifikan dari variabel kandidat tersebut. $\mathrm{Ha}_{1}$ diterima dan $\mathrm{Ho}_{1}$ ditiolak.

Ikatan kedaerahan secara parsial tidak memiliki pengaruh terhadap perilaku pemilih pemula dalam pemilihan legislatif tahun 2019 di Kecamatan Tilatang Kamang. Hal tersebut dibuktikan melalui hasil statistik pengolahan data menggunakan SPSS versi 25 didapatkan nilai sig variabel ikatan sosial sebesar 0,06 . Nilai sig tersebut lebih besar dari 0,05, dapat disimpulakan bahwa $\mathrm{Ho}_{2}$ diterima dan $\mathrm{Ha}_{2}$ ditolak.

Kandidat dan ikatan sosial secara simultan berpengaruh terhadap perilaku pemilih pemula dalam pemilihan legislatif tahun 2019 di Kecamatan Tilatang Kamang. Hal tersebut dibuktikan dari hasil statistik 
pengolahan data menggunakan SPSS versi 25 yang memaparkan bahwa nilah sig. F sebesar 0,000 yang diartikan bahwa adanya pengaruh dari variabel kandidat dan ikatan sosial secara bersamaan terhadap perilaku pemilih pemula dalam pemilihan legisltif tahun 2019 di Kecamatan Tilatang Kamang. Dan pengaruh variabel ikatan sosial (X1) dan ikatan sosial (X2) terhadap perilaku pemilih pemula dalam pemilihan legislatif tahun 2019 di Kecamatan Tilatang Kamang sebesar $32 \%$ dan sisanya $68 \%$ dipengaruhi variabel lain yang tidak diteliti dalam penelitian ini.

Penelitian ini memperkuat penelitianpenelitian terdahulu seperti penelitian Adnan (2012) tentang perilaku memilih pada pemilihan gubernur Sumatera Barat tahun 2005 yang menyatakan adanya pengaruh dari kandidat dilihat dari dua dimensi yaitu dimensi kepribadian dan kepemimpinan. Penelitian ini juga melihat aspek kepemimpinan, kompetensi, pengalaman, dan popularitas dari kandidat. Selain itu penelitian Emilia \& Wawan (2015) menemukan bahwa perilaku pemilih melihat atau memilih kandidat berdasarkan kesamaan kepercayaan atau kesamaan agama. Penelitian wattenberg (2006) dalam pemilihan presiden Amerika Serikat tahun 2004 menunjukan adanya pengaruh dimensi kepribadian kandidat terhadap perilaku pemilih. Selain itu penelitian Zul (20140 di kelurahan Mata Allo Kecamatan Bajeng Kabupaten Gowa menjelaskan bahwa perilaku pemilih pada pemilihan presiden 2014-2019 dipengaruhi olh beberapa faktor yakni citra kandidat, dan pemimpin yang berjiwa leadership. Pemilih pada daerah tersebut menentukan pilihannya berdasarkan figur kandidat yang memiliki sosok yang kharismatik dan sosok idaman bagi masyarakat di daerah tersebut. Akan tetapi dalam penelitian ini ikatan kedaerahan memiliki pengaruh atau menjadi faktor dari perilaku pemilih masyarakat di daerah tersebut.

Dari beberapa penelitian tersebut menunjukan bahwa para pemilih sudah sangat rasional dalam menentukan pilihannya. Pemilih melihat dari bagaimana image atau pandangan mereka kepada kandidat tersebut. Mereka mampu menilai kualitas dari kandidat yang ikut dalam pemilihan tersebut. Mereka tidak memandang kandidat tersebut dari sebuah ikatan sosial yang mereka miliki. Walaupun kandidat tersebut berasal dari keluarga mereka, memiliki ikatan kesukuan yang sama dan ikatan kedaerahan. Mereka lebih memilih kandidat yang memiliki jiwa kepemimpinan yang tinggi, kandidat yang memiliki kompetensi, kandidat yang memiliki popularitas di masyarakat. Selain itu penelitian ini dapat menjadi acuan bagi elit-elit partai untuk merekrut calon-calon atau kandidat yang akan ikut dalam pemilihan umum yang akan datang. Mereka dapat melihat kandidat yang akan maju berdasarkan dari aspek-aspek diatas.

\section{PENUTUP}

Berdasarkan hasil penelitian dan pembahasan yang telah dilakukan mengenai pengaruh kandidat dan ikatan sosial terhadap perilaku pemilih pemula dalam pemilihan legislatif tahun 2019 di Kecamatan Tilatang Kamang dapat ditarik kesimpulan bahwa:

1. Secara parsial terdapat pengaruh dari kandidat terhadap perilaku pemilih pemula dalam pemilihan legislatif tahun 2019 di Kecamatan Tilatang Kamang. Tidak terdapat pengaruh dari ikatan sosial terhadap perilaku pemilih pemula dalam pemilihan legislatif tahun 2019 di Kecamatan Tilatang Kamang.

2. Secara simultan terdapat pengaruh kandidat dan ikatan sosial terhadap perilaku pemilih pemula dalam pemilihan legislatif tahun 2019 di Kecamatan Tilatang Kamang. Besar pengaruh dari kandidat dan ikatan sosial ini sebesar $32 \%$ dan sisanya $68 \%$ dipengaruhi oleh variabel lain yang tidak diteliti dalam penelitian ini.

Berlatar belakang dari hasil penelitian dan kesimpulan yang telah diuraikan diatas, 
maka penulis memberikan saran-saran diantaranya:

1. Penelitian dapat menjadi acuan bagi elit-elite partai. Bahwa kandidat memiliki pengaruh terhdapa perilaku pemilih pemula. Elit partai dapat mensosialisasikan dan lebih mengenalkan lagi bagaimana kriteria kandidat atau calon yang akan diusungnya dalam pemilihan umum yang akan datang.

2. Penelitian ini dapat menjadi acuan bagi elit-elit partai untuk merekrut caloncalon atau kandidat yang akan ikut dalam pemilihan umum yang akan datang. Mereka dapat melihat kandidat yang akan maju berdasarkan dari aspekaspek ada pada penelitian ini.

3. Penelitian yang dilakukan masih terdapat berbagai kekurangan dan kelemahan. Untuk itu diharapkan kepada penelitian selanjutnya untuk mendalami lebih jauh lagi dengan melibatkan variabel lain yang mungkin juga akan berpengaruh terhadap perilaku pemilih pemula.

\section{DAFTAR KEPUSTAKAAN}

Adnan, M Fachri. 2012. Perilaku Memilih Pada Pemilihan Kepala Daearah Secara Langsung.UNP Press.Padang.

Miaz, Yalvema. 2012. Partisipasi Politik Pola Perilaku Pemilih Pada Masa Orde Baru dan Reformasi.UNP Press.Padang.

Surbakti, Ramlan. 1992. Memahami Ilmu Politik. Gramedia widiasarana. Jakarta.

Nur, Raoda, dkk. 2015. Perilaku Pemilih Pemula Dalam Pelaksanaan Pemilihan Presiden 2014 di Desa Kanaungan Kecamatan Labakkang Kabupaten Pangkep.Otoritas jurnal ilmu pemerintahan vol. V No. 1 April 2015. Makassar.

Sholihin, Mohammad. 2009. Perilaku Pemilih Buruh Rokok Dalam Pilkada
Langsung Di Kabupaten Kudus. Tesis. Universitas Diponegoro.

Haryanto. 2014. Kebangkitan Party ID: Analisis Perilaku Memilih dalam Politik Lokal di Indonesia. Jurnal Ilmu Sosial Politik Vol. 17, No. 3, Maret 2014.

Fitryah. 2013. Perilaku Pemilih Dalam Pilkada Kabupaten Kudus.Politika.vol.4. Kudus.

Diana, dkk. 2014. Sikap Pemilih Pemula Terhadap Calon Legislatif Partai Politik Ditinjau Dari Karakteristik Sosial. Jurnal Administrative Reform, Vol. 2 No. 2, tahun 2014.

Diah \& Mudzakhir. 2016. Rasionalitas Politik Pemilih Pemula Di Tegalsari Surabaya.Paradigma. Vol. 4 No. 01 Tahun 2016. Surabaya.

Suprojo, Agung. 2013. Analisis Tingkat Partisipasi Pemilih Pemula Pasca Ketetapan Komisi Pemilihan Umum Tentang 10 Partai Peserta Pemilu 2014 Dalam Pembangunan Politik Masyarakat.Jurnal Reformasi, Vol.3, No., Januari-Juli 2013. Universitas Tribhuana Tunggadewi.

Eta \& Nugrahedi. 2018. Partisipasi Politik Pemilih Pemula Pada Pemilihan Walikota Semarang Di Kota Semarang.Integralistik, No.1, Th. XXIX/2018. Semarang.

Emilia \& Wawan. 2015. Partisipasi Politik Dan Perilaku Memilih Pada Tahun 2014. Jurnal Penelitian Politik, Vol.12, No.1, Juni 2015.Jakarta.

Pontoh, Abdul Halil. 2013. Perilaku Memilih Masyarakat Bolaang Mongondow Utara Pada Pemilihan Umum Kepala Daerah Tahun 2013. Skripsi. Program Studi Ilmu Politik FISIP UNSRAT. 